\title{
Moralitas Ekonomi dalam Perspektif Budaya pada Mahasiswa
}

\author{
Damayanti $^{1}$, Sri Umi Mintarti Widjaja ${ }^{1}$, Agus Hermawan ${ }^{1}$ \\ ${ }^{1}$ Pendidikan Ekonomi-Universitas Negeri Malang
}

\begin{tabular}{l}
\hline \hline INFO ARTIKEL \\
\hline Riwayat Artikel: \\
Diterima: 11-07-2019 \\
Disetujui: $11-02-2020$ \\
\hline
\end{tabular}

\section{Kata kunci:}

economic morality; local culture; economic education students; moralitas ekonomi;

kearifan local; mahasiswa pendidikan ekonomi

\author{
Alamat Korespondensi: \\ Damayanti \\ Pendidikan Ekonomi \\ Universitas Negeri Malang \\ Jalan Semarang 5 Malang \\ E-mail: damayantidama7@gmail.com
}

\begin{abstract}
ABSTRAK
Abstract: This research is related to economic morality from the perspective of BugisMakassar local wisdom in economics education students at Makassar State University. Data in this study were collected based on documentation studies, in-depth interviews, and observations. Data analysis uses three processes, namely data condensation, data presentation, and data verification. Checking the validity of the findings was carried out with a credibility test with the stages of triangulation and extension of observation. Data analysis found morality in the perspective of Bugis-Makassar local wisdom, namely honesty, concern for others, and shame. The implications of the attitude on economic morality towards economic behavior are adherence to the rules of economic institutions, reminder and reduce economic disparity among UNM economic education students.
\end{abstract}

\begin{abstract}
Abstrak: Penelitian ini terkait moralitas ekonomi dalam perspektif kearifan lokal Bugis-Makassar pada mahasiswa Pendidikan Ekonomi di Universitas Negeri Makassar. Data dalam penelitian ini dikumpulkan berdasarkan studi dokumentasi, wawancara mendalam, dan observasi. Analisis data menggunakan tiga proses yaitu kondensasi data, penyajian data, dan verifikasi data. Pengecekan keabsahan temuan dilakukan uji kredibilitas dengan tahap triangulasi dan perpanjangan pengamatan. Dari analisis data ditemukan sikap moralitas dalam perspektif kearifan lokal Bugis-Makassar yakni kejujuran, kepedulian terhadap orang lain, dan rasa malu. Implikasi dari sikap pada moralitas ekonomi terhadap perilaku ekonomi yakni ketaatan pada aturan pranata ekonomi, reminder dan mengurang kesenjangan ekonomi diantara mahasiswa pendidikan ekonomi UNM.
\end{abstract}

Dalam perilaku ekonomi terdapat tindakan tidak berdasarkan atas kemauan (volitional behavior) dan tindakan yang terjadi dengan adanya unsur kewajiban (mandotary behavior), kedua tindakan ini tidak secara langsung terjadi, akan tetapi dimulai dengan tahapan sikap dam minat ekonomi terbentuk lebih dahulu (Jogiyanto,2007). Sikap ekonomi merupakan kondisi mental lengkap, dimana terdapat keyakinan, perasaan dan disposisi dalam pembawaan diri saat mengambil tindakan pada aktivitas ekonomi dengan cara tertentu, sedangkan minat ekonomi diartikan sebagai keinginan dalam melakukan perilaku ekonomi. Minat belum tentu menjadi faktor penentu terjadinya perilaku atau tindakan ekonomi karena hanya sebatas keinginan.

Menurut (Mir, 2018) ada hal penting yang harus diperhatikan didalam teori ekonomi mikro dan makro dasar, yaitu kemampuan mengintegrasikan nilai-nilai etika dan moral dalam pemetaan preferensi. Individu dalam perilaku ekonomi senantiasa tidak lepas diri dari pertimbangan moralitas. Moralitas yang turut menentukan perilaku ekonomi, dalam beberapa hal dapat menyebabkan manusia mengabaikan rasionalitas dalam perilaku ekonominya. Sesuai dengan penelitian yang dilakukan (Sutiany, Mashudi, \& Witarsa, 2013) moralitas ekonomi adalah bagian dari perilaku ekonomi yang berkaitan dengan sikap dan tindakan ekonomi seseorang dalam interaksinya dengan orang lain atau kelompok orang yang menekankan pada kepedulian seseorang terhadap keberadan orang lain. Moralitas mendorong manusia untuk mempertimbangkan masalah baik dan buruk dalam tindakan ekonominya. Istilah moralitas dapat diartikan sebagai wacana, pernyataan atau ajaran tentang moral, sedangkan moral sendiri secara umum dimaknai sebagai kondisi mental dan emosi, seperti antusiasme, kepercayaan, dan loyalitas individu atau kelompok mengenai suatu fungsi atau tugas yang diemban. Dalam hubungannya dengan kehidupan sosial kemasyarakatan, fungsi atau tugas yang dimaksud dalam pengertian tersebut, terkait dengan interaksi antar individu maupun individu dengan kelompok masyarakat lingkungannya dan dikategorikan dalam ukuran baik buruk sesuai dengan penerimaan masyarakat pada umumnya (Berkowitz dalam Wahyono, 2001). 
Jika diamati fenomena sekarang masyarakat banyak mengalami perubahan baik dari segi fungsi, teknologi, lifestyle, ekonomi dan bahkan norma-norma yang berlaku didalam masyarakat. Hal ini terjadi akibat dari adanya perubahan sistem adatistiadat yang ada dalam masyarakat. Perubahan tersebut tidak hanya terjadi pada masyarakat modern saja, tetapi sudah merambah pada masyarakat tradisional yang kental akan adat-istiadat sebagai norma dalam mengatur perilaku masyarakat. Salah satunya dapat kita lihat pada mahasiswa Pendidikan Ekonomi di Universitas Negeri Makassar (UNM) sebagai bagian dari masyarakat.

Pada dasarnya, mahasiswa diartikan sebagai sekumpulan pemuda yang memanfaatkan waktunya dengan menambah ilmu pengetahuan, skills, dan keahlian, serta kegiatan positif dengan harapan memiliki orientasi menjadi manusia yang berguna bagi masyarakat dimasa depan. Akan tetapi, dunia kampus memiliki gaya hidupnya sendiri di kalangan mahasiswa dengan adanya budaya mempertahankan harga diri dalam artian gengsi pada masing-masing mahasiswa. Perilaku yang demikian cenderung mengarah ke arah penyimpangan nilai-nilai hanya demi mempertahankan gengsi di lingkungan kampus sehingga perlu adanya pencegahan dan salah satu bentuknya adalah penerapan kearifan lokal Bugis-Makassar. Menurut (Dahliani, dkk , 2015) di dalam kearifan lokal, ada keselarasan antara manusia, alam, dan lingkungan yang dipengaruhi oleh kebudayaan yang berlaku masayarakat. Hal ini menjelaskan bahwa kearifan lokal adalah hasil dari manusia sebagai proses budaya sesuai dengan lingkungan alam sekitarnya dengan jangka waktu yang cukup panjang dan diturunkan dari generasi ke generasi.

Kearifan lokal sebenarnya suatu solusi yang sering digunakan dalam memecahkan suatu permasalahan dimasyarakat, baik dari segi lingkungan, pendidikan, sosial-politik maupun ekonomi. (Darojah, dkk, 2018) menjadikan kearifan lokal sebagai sumber instruksional bahan ajar untuk siswa SD dengan tujuan untuk mengapresiasi cerita fiksi dari kearifan lokal serta meningkatkan hasil belajar. Selain itu, (Rohayu, dkk, 2019) memanfaatkan kearifan lokal sebagai solusi konflik illegal logging yang ada di hutan Sumbawa. Sementara itu, (Habibi,dkk, 2018) menganggap bahwa nilai kearifan lokal dapat melindungi indentitas bangsa. Selain melindungi suatu bangsa, menurut (Herminingrum, dkk, 2017) kearifan lokal dapat dijadikan sebagai mitigasi bencana secara tradisional.

Unsur kearifan lokal yang sangat prinsip dalam kehidupan masyarakat Sulawesi Selatan adalah siri' dan pace'/passe' yang mengandung esensi nilai luhur yang universal. Siri' sebagai inti dari prinsip hidup Bugis-Makassar memiliki potensi menjadi motif penggerak kehidupan sosial dan pendorong tercapainya suatu prestasi sosial masyarakat Bugis-Makassar, sebab siri' merupakan pandangan hidup yang bertujuan untuk meningkatkan harkat, martabat dan harga diri, baik sebagai individu maupun sebagai makhluk sosial. Konsep lain yang erat kaitannya dengan siri' adalah pacce'/passe' yang merupakan wujud rasa solidaritas terhadap penderitaan orang lain. Rasa solidaritas mengandung makna keinginan membantu sesama manusia yang memiliki kesulitan dan penderitaan.

Dari hasil kajian sementara tentang fenomena moralitas yang kemungkinan terjadi pada mahasiswa di Universitas Negeri Makassar, maka dipandang perlu untuk mengungkap tentang moralitas ekonomi dilihat dari kearifan lokal BugisMakassar pada mahasiswa Pendidikan Ekonomi Universitas Negeri Makassar dengan fokus penelitian menganalisis sikap dan implikasi moralitas dalam perspektif kearifan lokal terhadap perilaku ekonomi mahasiswa Pendidikan Ekonomi di Universitas Negeri Makassar.

\section{METODE}

Penelitian ini menerapkan pendekatan penelitian kualitatif. Jenis penelitian yang digunakan pada penelitian ini yaitu penelitian Etnografi dimana mendeskripsikan dan menganalisis suatu budaya, dalam hal ini kearifan lokal BugisMakassar.Lokasi penelitian ini terletak di Pendidikan Ekonomi, Fakultas Ekonomi Universitas Negeri Makassar. Prosedur pengumpulan data menggunakan teknik wawancara mendalam, observasi partisipan, dan dokumentasi. Analisis data pada penelitian ini dimulai pada saat peneliti melakukan studi pendahuluan pada mahasiswa pendidikan ekonomi UNM, kemudian berlanjut menelaah setelah data diperoleh dari wawancara mendalam, observasi, dan dokumentasi. Data yang diperoleh dari hasil wawancara dan pengamatan selanjutnya dipelajari dan ditelaah.

\section{HASIL}

Dari hasil penelitian di lapangan ditemukan bahwa adanya sikap moralitas ekonomi dalam perspektif budaya lokal Bugis-Makassar serta implikasinya terhadap perilaku ekonomi mahasiswa Pendidikan Ekonomi UNM (Tabel 1).

Tabel 1. Hasil Penelitian Lapangan terhadap Mahasiswa Pendidikan Ekonomi UNM

\begin{tabular}{llll}
\hline No. & Moralitas Ekonomi & Sikap (perspektif kearifan lokal Bugis-Makassar) & Implikasi \\
\hline 1 & Imperatif & Kejujuran & Ketaatan pada aturan pranata Ekonomi \\
2 & Tenggang Rasa & Kepedulian terhadap orang lain & Reminder \\
3 & Komitmen & Rasa Malu & Resenjangan Ekonomi \\
\hline
\end{tabular}


Kejujuran dalam kearifan lokal siri' na pacce' memiliki makna bahwa ada ketaatan pada aturan pranata dalam perekonomian dan hal ini termasuk kedalam moralitas imperatif. Imperatif diartikan sebagai ketaatan terhadap pranata pada perekonomian dan pemenuhan kewajiban pada perekonomian. Dari hasil penelitian, responden memiliki pandangan bahwa kejujuran itu menjadi hal penting dalam perilaku ekonomi, utamanya dalam dunia usaha. Jika ada yang melakukan perilaku yang tidak jujur, akan menimbulkan rasa malu dalam diri mereka sebagai suatu sanksi sosial. Moralitas ekonomi menekankan bagaimana sikap dan tindakan seseorang kepada orang lain serta kepeduliannya terhadap orang lain. Dari hasil temuan dalam penelitian ini ada sikap kepedulian terhadap orang lain. Bentuk kepedulian ini dengan menolong orang-orang disekitar mereka dalam hal ini sesama mahasiswa pendidikan ekonomi jika ada yang membutuhkan, misalnya dengan meminjamkan uang atau yang lainnya saat mereka membutuhkan. Sikap peduli ini mewakili indikator tenggang rasa yang ada pada moralitas ekonomi. Tenggang rasa bermakna peduli terhadap keberadaan orang lain dan kemampuan menimbang dampak tindakan terhadap pihak lain. Nilai-nilai kearifan lokal siri' na pacce' sebagai moralitas ekonomi, menekankan pada penting menghargai keberadaan orang lain dalam kehidupan sosial sehingga tercipta kesetaraan dengan tidak adanya persaingan yang merugikan satu sama lain.

Sikap yang mengutamakan norma moral dalam perilaku ekonomi merupakan komitmen pada moralitas ekonomi. Ketika ada suatu pelanggaran atau perilaku tidak menyalahi atau tidak sesuai dengan norma moral akan menimbulkan rasa malu. Rasa malu yang merupakan kearifan lokal Bugis-Makassar berdasarkan hasil temuan dirasakan oleh mahasiswa pendidikan ekonomi apabila tidak mengutamakan moral dalam perilaku ekonomi mereka, misalnya menggunakan barang-barang yang tidak melalui prosedur yang sebenarnya atau dalam hal ini ilegal. Dengan adanya rasa malu ini memberikan dampak kepada perilaku ekonomi mahasiswa, ada reminder atau peringatan untuk tidak melakukan pelanggaran-pelanggaran dalam perilaku ekonomi serta selalu memikirkan dampak dari setiap tindakan yang diambil terhadap orang lain.

\section{PEMBAHASAN}

Budaya lokal Bugis-Makassar dikenal dengan prinsip hidup Siri' na pace. Siri' na pacce' telah diwariskan secara turun temurun oleh leluhur orang Bugis Makassar. Siri' na pacce secara maknawi berarti harga diri. Ketika harga diri orang Bugis Makassar dilecehkan, maka pantang bagi dirinya untuk diam. Dengan kata lain mereka akan melakukan perlawanan demi mempertahankan harga dirinya daripada harus menanggung malu. Hal ini dikarenakan, nilai siri' na pace yang telah dilecehkan akan berakibat pada hilangnya harga diri yang sangat dijunjung tinggi nilainya dalam kehidupan sosial bermasyarakat. Selain itu, menimbulkan kesan perasaan malu kepada lingkungan sosial jika siri' na pacce' tidak dipertahankan.

Hasil yang diperoleh bahwa saat ini mahasiswa mulai memahami pentingnya moralitas ekonomi dalam perilaku ekonomi. Ada prinsip yang mereka pegang sebagai pengingat dalam melakukan suatu hal. Prinsip tersebut berbeda-beda pada setiap mahasiswa, ada yang memegang prinsip agama, maupun prinsip lain yang mereka serap dari kehidupan sosial di lingkungan mereka, tetapi inti dari prinsip tersebut tidak jauh berbeda dengan makna yang ada pada kearifan lokal siri' na pacce' pada suku Bugis-Makassar. Perbedaan prinsip yang dipegang oleh mahasiswa tersebut membuktikan adanya pergeseran penerapan kearifan lokal Bugis-Makassar dalam hal ini siri' na pacce' pada kehidupan mahasiswa. Hal ini disebabkan adanya pengaruh modernisasi yang disebabkan perkembangan zaman yang mau tidak mau memengaruhi pola pikir mahasiswa. Mereka yang terlahir pada keluarga yang menganut prinsip siri' na pacce' tentu saja ada pelajaran yang mereka dapatkan dari lingkungan keluarga, walaupun pada akhirnya mereka menentukan sendiri pegangan hidup seperti apa yang akan mereka terapkan dalam perilaku ekonominya. Hal ini sesuai dengan penelitian yang dilakukan oleh Basri (2011) yang menyatakan bahwa sikap dan minat ke dalam moralitas ekonomi terinternalisasi melalui sekolah, orangtua/keluarga, pengajian/rohanian, media informasi dan masyarakat sekitar membentuk jalur terinternalisasi yang dominan dalam membentuk moralitas ekonomi mahasiswa.

Nilai-nilai yang terdapat dalam ajaran kearifan lokal siri' na pacce' yang bernilai moralitas ekonomi berupa kejujuran, kepedulian terhadap orang lain, dan rasa malu memberikan pengaruh kepada mahasiswa dalam menentukan sikap pada perilaku ekonomi. Ada pertimbangan dalam bersikap pada perilaku ekonomi mahasiswa dengan memperhatikan moralitas ekonomi, dengan Hal ini sesuai dengan hasil temuan pada penelitian yang dilakukan oleh Hasyim (2006) yang menemukan bahwa pada interaksi ekonomi beberapa kriteria moral memiliki peran yang penting dalam keputusan ekonomi. Harga diri dan kejujuran tidak sejalan dengan rasionalitas ekonomi serta kepatuhan pada religi dan kebudayaan setempat yang lebih mengutamakan hubungan baik antara sesama, daripada motif keuntungan juga tidak sesuai denga rasionalitas ekonomi.

Dari hasil temuan pada penelitian ini, kearifan lokal siri' na pacce' dalam penerapannya sebagai moralitas ekonomi terhadap perilaku ekonomi mahasiswa pendidikan ekonomi menjadi reminder dalam bertindak. Ada suatu peringatan sebagai pengendali dalam melakukan suatu perilaku ekonomi, agar tidak terjadi pelanggaran aturan pranata dalam perekonomian, dan agar mahasiswa juga lebih mempertimbangkan dampaknya terhadap orang-orang disekitar mereka dalam setiap perilaku ekonomi yang mereka lakukan. Hal ini sejalan dengan pernyataan (Syarif, dkk, 2016) pada penelitiannya bahwa pengaplikasian nilai kultur Bugis-Makassar memiliki fungsi sebagai filter dalam menghadapi era Masyarakat Ekonomi Asean (MEA). Dengan mengkaji nilai budaya siri' dan pacce yang kemudian diterapkan dalam pembelajaran diharapkan dapat membangun karakter bangsa didalam setiap peserta didik. Dengan adanya kearifan lokal siri' na pacce' sebagai moralitas ekonomi, dimana menekankan pada pentingnya kehidupan sosial yang menghargai keberadaan orang lain di sekitar kita, menjadikan tidak adanya persaingan-persaingan negatif yang terjadi yang akan merugikan satu sama lain dan tidak ada tindakan ekonomi yang tidak dianjurkan terjadi di masyarakat dalam hal ini mahasiswa Pendidikan Ekonomi. Kesenjangan ekonomi menjadi berkurang atau 
bahkan tidak ada lagi. Hal tersebut sesuai dengan penelitian yang dilakukan oleh (Basri, 2011) yang menyatakan bahwa dalam moralitas ekonomi kriteria simetri bermakna adanya kemampuan menimbang dampak aktivitas ekonomi dan penghargaan persamaan hak dalam aktivitas ekonomi, adanya kesediaan untuk setara dengan orang lain dalam keadaan yang sebanding, kedudukan atau hak yang sama.

\section{SIMPULAN}

Moralitas ekonomi dalam perspektif kearifan lokal Bugis-Makassar ada pada diri mahasiswa Pendidikan Ekonomi, tetapi dalam penerapannya ada pergeseran akibat modernisasi, beberapa mahasiswa lebih menerapkan prinsip agama maupun prinsip lain yang mereka dapatkan dari lingkungan mereka sendiri, namun maknanya hampir sama dengan makna dari siri' na pacce' itu sendiri. Sikap moralitas ekonomi dalam kearifan lokal siri' na pacce pada suku Bugis-Makassar yakni adanya kejujuran, kepedulian terhadap orang lain dan rasa malu. Kejujuran memberikan sikap imperatif dalam menaati aturan perekonomian pada perilaku ekonomi. Kepedulian terhadap orang lain memberikan sikap tenggang rasa dengan saling tolongmenolong dalam perilaku ekonomi sebagai bentuk kepedulian terhadap orang lain. Rasa malu memberikan sikap komitmen terhadap norma moral yang berlaku pada setiap perilaku ekonomi, adanya rasa malu ketika dalam perilaku ekonomi terjadi ketidaksesuaian dengan norma yang berlaku didalam masyarakat, sedangkan implikasi moralitas ekonomi dalam perspektif kearifan lokal Bugis-Makassar pada mahasiswa Pendidikan Ekonomi Fakultas Ekonomi Universitas Negeri Makassar yakni sebagai reminder dalam perilaku ekonomi dan mengurangi kesenjangan ekonomi. Kearifan lokal siri' na pacce' pada masyarakat Bugis-Makassar memiliki nilai-nilai yang dapat mengendalikan perilaku ekonomi agar tetap sesuai dengan aturan pranata dalam perekonomian. Dengan adanya moralitas ekonomi dalam perspektif kearifan lokal, menjadikan mahasiswa memahami pentingnya menghargai keberadaan orang lain di sekitar kita sehingga tidak terjadi tindakan yang tidak dianjurkan dalam ekonomi dan tidak terjadi kesenjangan dalam ekonomi.

Berdasarkan permasalahan dan hasil penelitian diatas, ada empat saran yang dapat menjadi pertimbangan demi mempertahankan eksistensi nilai-nilai kearifan budaya lokal Bugis-Makassar terkait dengan moralitas ekonomi. Keempat saran tersebut diuraikan berikut ini. Pertama, bagi masyarakat. Diharapkan agar masyarakat dapat memberikan kontribusi dan kepedulian yang lebih besar dalam proses pewarisan nilai-nilai kearifan lokal Bugis-Makassar terkait dengan moralitas ekonomi dalam perilaku ekonomi sehingga kelestariannya tetap terjaga sampai generasi-generasi berikutnya. Kedua, bagi pemerintah. Pemerintah diharapkan dapat mengembangkan berbagai pewarisan nilai-nilai kearifan lokal terkait dengan moralitas ekonomi dengan mempublikasikan melalui berbagai media sehingga masyarakat luas mengenal pewarisan nilai-nilai tersebut. Ketiga, bagi perguruan tinggi, mengintensifkan peran Pendidikan Ekonomi untuk menumbuhkan kesadaran peserta didik, mahasiswa dan masyarakat untuk memperhatikan nilai-nilai budaya dan potensi lokal dalam setiap aktivitas ekonomi. Keempat, bagi peneliti selanjutnya, sebagai peneliti selanjutnya perlu menindaklanjuti dengan melaksanakan penelitian lanjutan berupa penelitian pengembangan terkait dengan nilai-nilai kearifan lokal dalam pendidikan ekonomi baik untuk pendidikan informal, pendidikan nonformal maupun pendidikan formal.

\section{DAFTAR RUJUKAN}

Basri, M. (2011). Internalisasi Sikap dan Minat ke dalam Moralitas Ekonomi Mahasiswa Fakultas Ekonomi Program Kependidikan Universitas Negeri Malang. Tesis tidak diterbitkan. Universitas Negeri Malang, Malang.

Dahliani, D., Soemarno, I., \& Setijanti, P. (2015). Local Wisdom in Built Environment in Globalization Era. International Journal of Education and Research, 3(6), 157-166.

Darojah, R., Winarni, R., \& Murwaningsih, T. (2018). International Journal of Multicultural and Multireligious Understanding The Local Culture Values of "Perdikan Cahyana " as a Source of Instructional Material for Elementary Students. 69-78.

Habibi, H. (2018). Protecting National Identity Based on the Value of Nation Local Wisdom. International Journal of MalayNusantara Studies, 1(2), 24-40.

Herminingrum, S., \& Junining, E. (2017). Socio-Cultural Life of Kelud People in Connecting with Traditional Mitigation Effort Based on Local Wisdom. International Journal of Social and Local Economic Governance, 2(2), $127-135$. https://doi.org/10.21776/ub.ijleg.2016.002.02.4

Jogiyanto. (2007). Sistem Informasi Keprilakuan. Yogyakarta. Penerbit Andi.

Mir, K. (2018). Economics, Finance, Business \& Industry, Humanities. Ethics and Economic Theory, 1-230. https://doi.org/10.4324/9781351184458

Rohayu, R., \& Absori. (2019). Utilizing the Values of Local Wisdom. International Journal of Social Sciences and Humanities, 3(1), 91-101. https://doi.org/10.29332/ijssh.v3n1.263

Sutiany, H., Mashudi., \& Witarsa (2014). Internalisasi Moralitas Ekonomi Mahasiswa Program Studi Pendidikan Ekonomi FKIP Untan. Jurnal Pendidikan dan Pembelajaran Khatulistiwa, 3(2), 1-13.

Syarif, E., Fatchan, A., \& Astina, I. K. (2016). Dalam Proses Pembelajaran sebagai Salah Satu Strategi Menghadapi Era Masyarakat Ekonomi Asean (MEA). Jurnal Teori dan Praksis Pembelajaran IPS, 1(1), 13-21.

Wahyono, H. (2001). Pengaruh Perilaku Ekonomi Kepala Keluarga terhadap Intensitas Pendidikan Ekonomi di Lingkungan Keluarga. Disertasi tidak diterbitkan. Universitas Negeri Malang, Malang. 